\title{
Age structure, growth and mortality of the striped goby, Gobius vittatus (Gobiidae) in the northern Adriatic Sea
}

\author{
MARCELO KOVAČIĆ \\ Prirodoslovni muzej Rijeka, Lorenzov prolaz 1, HR-51000 Rijeka, Croatia. E-mail: Marcelo.Kovacic@public.srce.hr
}

\begin{abstract}
SUMMARY: The striped goby, Gobius vittatus Vinciguerra, 1883 is a Mediterranean gobiid species considered to be rare with very little data on its biology and ecology. A sample of 704 specimens of G. vittatus was collected by SCUBA diving at three locations in the northern Adriatic Sea (Kvarner area) from April 2001 to March 2002. The present paper provides the first information on age structure, lifespan, growth and mortality of $G$. vittatus. The size range of individuals was between 19.2 and $54.0 \mathrm{~mm}$. The maximum estimated age was 4 and 3 years for females and males respectively. The total mortality rate $(\mathrm{Z})$ was estimated to be from 0.94 to 1.08 for females and from 0.99 to 1.43 for males. The von Bertalanffy growth parameters estimated from the mean monthly age-length data were significantly different between sexes (females: $\mathrm{L}_{\infty}=$ $50.96, \mathrm{~K}=1.02$ and $\mathrm{t}_{0}=-0.47$; males: $\mathrm{L}_{\infty}=50.13, \mathrm{~K}=1.18$ and $\left.\mathrm{t}_{0}=-0.42\right)$.

Keywords:: Gobius vittatus, age structure, growth, mortality, Adriatic Sea.

RESUMEN: ESTRUCTURA DE EDADES, CRECIMIENTO Y MORTALIDAD DE GOBIUS VITTATUS (GOBIIDAE) EN EL NORTE DEL MAR ADRIÁTICO. - El gobio listado (Gobius vittatus, Vinciguerra, 1883) es una especie mediterránea considerada rara y de la que se tienen pocos datos sobre su biología y ecología. Un total de 704 individuos de esta especie fueron capturados mediante inmersión con escafandra autónoma en tres localidades de la región de Kvamer, en el norte del Adriático, desde abril de 2001 hasta marzo de 2002. En este trabajo se presentan los primeros datos sobre la estructura de edades, crecimiento, longevidad y mortalidad de $G$. vittatus. El rango de tallas se situó entre 19.2 y $54.0 \mathrm{~mm}$. La hembra de mayor edad tenía 4 años mientras que ningún macho superó los 3 años. La estima de la tasa de mortalidad varió entre 0.94 y 1.8 , para las hembras, y entre 0.99 y 1.43 para los machos. Los paramétros de crecimiento de von Bertalanffy, evaluados a partir de los valores medios de talla-edad por mes, resultaron ser significativamente diferentes entre sexos (hembras : $\mathrm{L}_{\infty}=50.96, \mathrm{~K}=1.02 \mathrm{y} \mathrm{t}_{0}=-0.47$; machos: $\left.\mathrm{L}_{\infty}=50.13, \mathrm{~K}=1.18 \mathrm{y} \mathrm{t}_{0}=-0,42\right)$.
\end{abstract}

Palabras clave: Gobius vittatus, estructura de edades, crecimiento, mortalidad, mar Adriático.

\section{INTRODUCTION}

The striped goby, Gobius vittatus Vinciguerra, 1883 is a poorly known Mediterranean gobiid species. The morphology and habitat of this species are known from a few papers, each based on one or two specimens (Vinciguerra, 1883; Kolombatović, 1886, 1891; Fage, 1918; De Buen, 1923; Tortonese, 1975). Due to the lack of data, the species was con- sidered to be rare or very rare (Tortonese, 1975; Jardas, 1985). The only published paper on the biology of G. vittatus is based on 21 specimens from Banylus-sur-Mer (France) and reports data on habitat, diet and morphology (Heymer and Zander, 1978). The present paper provides the first information on age structure, lifespan, mortality and growth of G. vittatus collected in the northern Adriatic Sea (Kvarner area). 


\section{MATERIAL AND METHODS}

Seven hundred and four specimens of G. vittatus were obtained in three locations (Stara voda, Oštro and Selce) in the Kvarner area, northern Adriatic Sea, from April 2001 to March 2002 (Fig. 1). All fish were collected between 8 and $20 \mathrm{~m}$ depth, using a hand net and the anaesthetic quinaldine during SCUBA dives. Twenty specimens were collected at each location during one dive every month. However, only four specimens were collected in January at Oštro due to bad weather and low temperatures. During the SCUBA dives the water temperature was measured at the sea surface and at the collecting depth. All specimens were killed by overanaesthetization with quinaldine and fixed in $65 \%$ alcohol.

In the laboratory, the total length (TL) of each individual was measured to the nearest $0.1 \mathrm{~mm}$ (and pooled in $5 \mathrm{~mm}$ length classes). The specimens were sexed by inspecting gonad morphology. Sagittal otoliths were used to estimate age and growth of $G$. vittatus. Otoliths were cleaned, immersed in glycerol, and examined on a black background using reflected light at low magnification $(2.5 \times 16)$ (Kovačić, 2001). Assuming a birth date of June 1, which corresponds approximately to the spawning period peak (Kovačić, 2004), age was assigned according to the number of translucent bands (Miller, 1961). Young of the year (i.e. fish of age 0) were considered to be those with just a translucent nucleus and a more or less developed opaque edge. At least one otolith from each specimen was readable. Otoliths were read twice by the author, with time intervals between readings. Only coincident readings were accepted. The index of average percentage error (IAPE) (Beamish and Fournier, 1981), was used to assess the precision of age determination. The von Bertalanffy growth function (VBGF) for each sex was fitted to mean monthly age-length data by means of the quasi-Newton algorithm for non-linear least square estimation of growth parameters (Sparre and Venema, 1992):

$$
\mathrm{TL}=\mathrm{L}_{\infty}\left(1-\mathrm{e}^{-\mathrm{K}(\mathrm{t}-\mathrm{t} 0)}\right)
$$

where $\mathrm{TL}=$ total length at age $\mathrm{t}, \mathrm{L}_{\infty}=$ asymptotic length, $\mathrm{K}=$ growth coefficient and $\mathrm{t}_{0}=$ theoretical age at zero length. Mean monthly data were used to reduce the variability associated with all-year round sampling, where the specimens of the same age

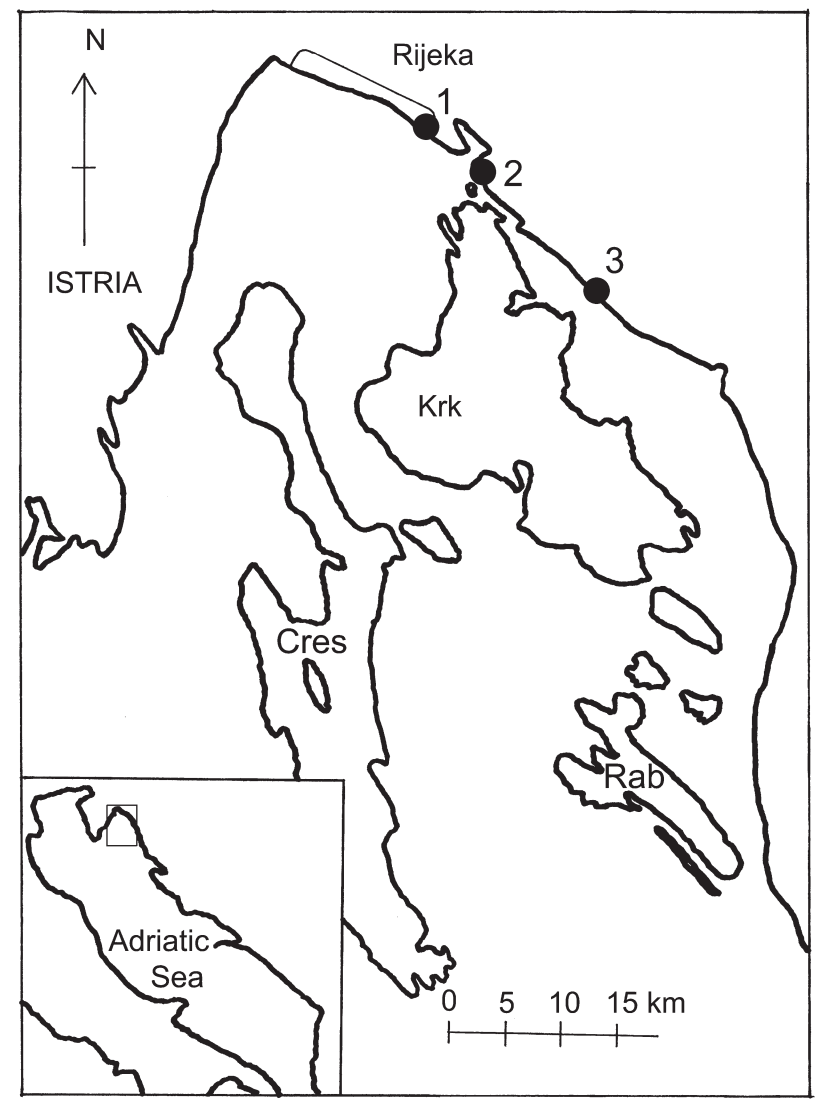

FIG. 1. - The Kvarner area, Croatia. Collecting sites: (1) Stara voda, (2) Oštro and (3) Selce.

class differ considerably in age and growth (Labropoulou et al., 1998). Only mean values from samples equal to or greater than five fish were used. The goodness-of-fit was represented by the coefficient of determination $\left(\mathrm{r}^{2}\right)$. The growth parameters obtained for males and females were compared using the multivariate Hotelling's $\mathrm{T}^{2}$-test (Bernard, $1981)$. Finally, the growth performance index $\left(\Phi^{\prime}=\right.$ $2 \log \mathrm{L}_{\infty}+\log \mathrm{K}$ ) (Munro and Pauly, 1983) was used to compare the growth of $G$. vittatus with other Mediterranean Gobius species. The total mortality rate $(\mathrm{Z})$ of $G$. vittatus is equivalent to the natural mortality rate $(\mathrm{M})$, since the species cannot be collected by conventional fishing gears and therefore there is no fishing mortality. The linearized catch curve based on age composition data was used to estimate Z (Sparre and Venema, 1992). The estimate of $\mathrm{Z}$ from the age composition data was compared with the results obtained by applying indirect methods proposed by Sparre and Venema (1992): Pauly's equation relates $\mathrm{M}$ to growth parameters and ambient temperature, Rikhter and Efanov's method relates $\mathrm{M}$ to the age of massive maturation, Hoenig's 
model 1 relates $\mathrm{Z}$ to observed longevity; and the Djabali et al. (1994) equation relates $M$ to growth parameters for Mediterranean teleost fish. The longevity for each value of natural mortality (= total mortality) was estimated using the method by Alagaraja (1984) to choose the best estimate of natural mortality.

The non-linear estimation of the parameters of VBGF and variance-covariance matrices of growth parameters used for the Hotelling's $\mathrm{T}^{2}$-test was calculated using Statistica 5.1. FiSAT II software was used for Pauly's M equation, Rikhter and Efanov's method and Hoenig's model (Gayanilo et al., 2002). Other data analyses were carried out using the Excel 2002 and the SPSS 9.0 programs.

\section{RESULTS}

\section{Growth}

The size range of the individuals caught was from 19.2 to $52.6 \mathrm{~mm}$ in males and from 20.1 to $54.0 \mathrm{~mm}$ in females (Fig. 2). Out of the 704 specimens examined (402 females and 302 males), 677 specimens (383 females and 294 males) were aged successfully. The value of the IAPE was $1.8 \%$. The mean monthly size within the same age group changed considerably with growth in the youngest individuals (Table 1). Indeed, G. vittatus attains over $50 \%$ of their maximum observed size during the first year of life. A total of 34 monthly samples of females and 22 monthly samples of males (with more than five fish), which together account for $91.7 \%$ of the total sample size, were used for the

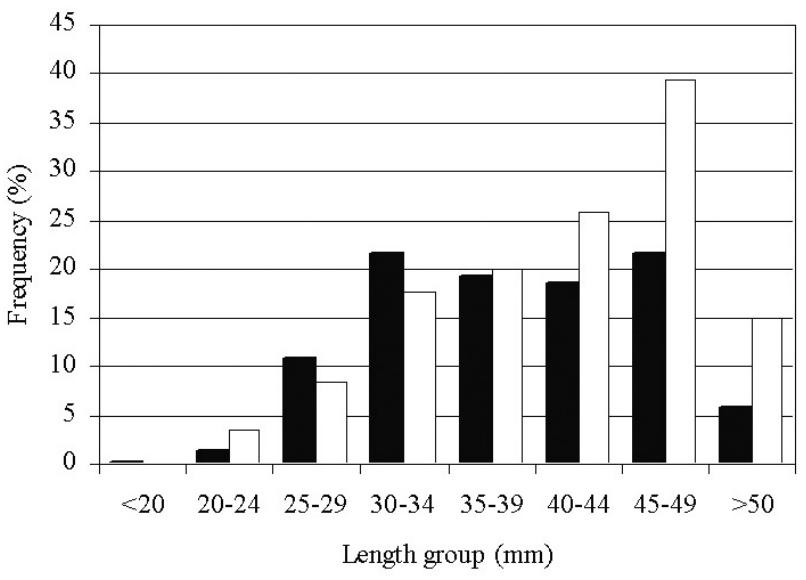

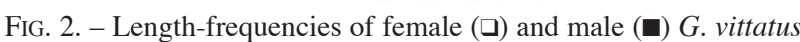
from the Kvarner area.
TABLE 1. - Mean monthly length-at-age data used for fitting the von Bertalanffy growth function (VBGF) for females and males of $G$. vittatus from the Kvarner area. Date of birth was set at 1 June (see text).

\begin{tabular}{|c|c|c|c|c|c|}
\hline \multirow{2}{*}{$\begin{array}{l}\text { Age } \\
\text { (years) }\end{array}$} & \multicolumn{2}{|c|}{ Females } & \multicolumn{3}{|c|}{ Males } \\
\hline & $\mathrm{n}$ & $\mathrm{TL}(\mathrm{mm})$ & $\mathrm{n}$ & & $(\mathrm{mm})$ \\
\hline 0.17 & 7 & 22.3 & & & \\
\hline 0.25 & 12 & 27.1 & 15 & & 27.8 \\
\hline 0.33 & 16 & 30.4 & 19 & & 29.6 \\
\hline 0.42 & 13 & 32.6 & 19 & & 33.4 \\
\hline 0.50 & 17 & 33.8 & 13 & & 34.0 \\
\hline 0.58 & 9 & 32.7 & 17 & & 33.8 \\
\hline 0.67 & 10 & 31.9 & 24 & & 34.1 \\
\hline 0.75 & 14 & 32.9 & 24 & & 34.0 \\
\hline 0.83 & 12 & 37.8 & 14 & & 38.5 \\
\hline 0.92 & 18 & 37.8 & 14 & & 38.8 \\
\hline 1.00 & 20 & 39.4 & 8 & & 41.1 \\
\hline 1.08 & 16 & 40.8 & 11 & & 41.5 \\
\hline 1.17 & 18 & 43.0 & 12 & & 44.1 \\
\hline 1.25 & 7 & 45.6 & 7 & & 45.3 \\
\hline 1.33 & 10 & 43.5 & 5 & & 46.1 \\
\hline 1.42 & 7 & 44.8 & 8 & & 44.7 \\
\hline 1.50 & 11 & 43.5 & 6 & & 46.3 \\
\hline 1.58 & 9 & 44.1 & 7 & & 44.7 \\
\hline 1.67 & 9 & 44.1 & 9 & & 45.8 \\
\hline 1.75 & 8 & 46.2 & 8 & & 46.0 \\
\hline 1.83 & 7 & 44.0 & & & \\
\hline 2.00 & 9 & 45.9 & & & \\
\hline 2.08 & 13 & 47.6 & & & \\
\hline 2.17 & 9 & 47.5 & 7 & & 46.1 \\
\hline 2.25 & 8 & 49.4 & 8 & & 47.1 \\
\hline 2.33 & 6 & 48.8 & & & \\
\hline 2.42 & 8 & 47.5 & & & \\
\hline 2.50 & 6 & 48.5 & & & \\
\hline 2.83 & 9 & 48.8 & 5 & & 49.3 \\
\hline 2.92 & 9 & 47.5 & & & \\
\hline 3.00 & 15 & 49.3 & & & \\
\hline 3.08 & 6 & 50.9 & & & \\
\hline 3.83 & 7 & 51.2 & & & \\
\hline 3.92 & 6 & 50.3 & & & \\
\hline
\end{tabular}

estimates of the von Bertalanffy growth parameters (Table 1). The estimates of the Bertalanffy growth parameters $\left(\mathrm{L}_{\infty}, \mathrm{K}\right.$ and $\left.\mathrm{t}_{0}\right)$ for females and males, as well as their asymptotic standard errors, are shown in Table 2. Significant differences in growth parameters were found between sexes (Hotelling's $\mathrm{T}^{2}$-test, $\left.\mathrm{T}^{2}=235.8>\mathrm{T}_{0(0.05,3,52)}^{2}=12.52\right)$. The $\mathrm{L}_{\infty}$ value was higher in females and the $\mathrm{K}$ value was higher in

TABLE 2. - The estimates of the von Bertalanffy growth parameters $\left(\mathrm{L}_{\infty}, \mathrm{K}\right.$ and $\left.\mathrm{t}_{0}\right)$ for females and males of G. vittatus from the Kvarner area $\left(\mathrm{r}^{2}\right.$ coefficient of determination, ASE asymptotic standard error).

\begin{tabular}{lcccc}
\hline \multirow{2}{*}{ Parameter } & \multicolumn{2}{c}{ Females } & \multicolumn{2}{c}{ Males } \\
& Estimate & ASE & Estimate & ASE \\
& & & & \\
$\mathrm{L}_{\infty}$ & 50.96 & 0.93 & 50.13 & 1.76 \\
$\mathrm{~K}$ & 1.02 & 0.12 & 1.18 & 0.24 \\
$\mathrm{t}_{0}$ & -0.47 & 0.09 & -0.42 & 0.13 \\
$\mathrm{r}^{2}$ & 0.961 & & 0.950 & \\
\hline
\end{tabular}


TABLE 3. - Mean length-at-age \pm S.D. for females and males of G. vittatus from the Kvarner area.

\begin{tabular}{|c|c|c|c|c|}
\hline \multirow{2}{*}{$\begin{array}{l}\text { Age } \\
\text { (years) }\end{array}$} & \multicolumn{2}{|c|}{ Females } & \multicolumn{2}{|c|}{ Males } \\
\hline & $\mathrm{n}$ & $\mathrm{TL}(\mathrm{mm})$ & $\mathrm{n}$ & $\mathrm{TL}(\mathrm{mm})$ \\
\hline 0 & 128 & $32.6 \pm 4.7$ & 163 & $33.3 \pm 4.7$ \\
\hline 1 & 126 & $43.1 \pm 3.6$ & 85 & $44.3 \pm 2.8$ \\
\hline 2 & 81 & $47.9 \pm 2.2$ & 38 & $48.3 \pm 2.8$ \\
\hline 3 & 41 & $50.1 \pm 1.9$ & 8 & $50.7 \pm 2.0$ \\
\hline 4 & 7 & $51.6 \pm 1.9$ & & \\
\hline
\end{tabular}

males. Therefore, females would attain a bigger size than males. However, males grew faster than females, considering growth coefficient $\mathrm{K}$ and average lengths of age groups (Table 3 ). The growth performance index was similar for both sexes, contrary to Hotelling's $\mathrm{T}^{2}$-test and the considerable differences between the $\mathrm{K}$ values of females and males (Table 4).

\section{Age structure, longevity and mortality}

The age-frequency distribution was unimodal in both sexes, and the youngest age group ( $0+$ fish) was the dominant age class (Fig. 3). The average age of collected females was higher than that of males

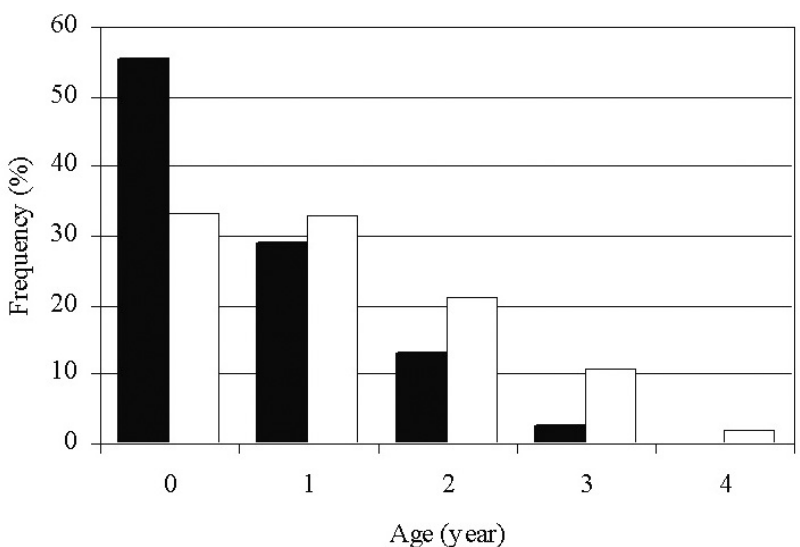

FIG. 3. - Age-frequency distributions for female ( $(\square)$ and male G. vittatus from the Kvarner area.

(Mann - Whitney U-test: Z=-6.57, P<0.001) (Fig. 3 ). The observed longevity was different for females and males. The maximum observed age was 4 and 3 years for females and males respectively.

The various methods applied yielded variable mortality estimates (Table 5). The values of M estimated following Pauly's equation and Rikhter and Efanov's method had to be rejected because, considering the observed longevity of females, the esti-

TABLE 4. - Von Bertalanffy growth parameters $\left(\mathrm{L}_{\infty}\right.$ and $\mathrm{K}$ ) and growth performance indexes $\left(\Phi^{\prime}\right)$ for Gobius species (*estimation of growth parameters based on data from Miller, 1961; **estimation of growth parameters based on data from Dunne, 1978).

\begin{tabular}{|c|c|c|c|c|}
\hline Species & $\mathrm{L}_{\infty}$ & $\mathrm{K}$ & $\Phi$ & Source \\
\hline G. vittatus males & 50.1 & 1.18 & 3.47 & This paper \\
\hline G. vittatus females & 51.0 & 1.02 & 3.42 & This paper \\
\hline$G$. roulei males & 90.6 & 0.21 & 3.23 & Kovačić, 2001 \\
\hline G. roulei females & 80.0 & 0.22 & 3.15 & Kovačić, 2001 \\
\hline G. paganellus & 127.7 & 0.89 & 4.16 & Azevedo and Simas, 2000 \\
\hline G. paganellus & 120.0 & 0.31 & 3.65 & Azevedo and Simas, 2000* \\
\hline G. paganellus & 141.5 & 0.27 & 3.73 & Azevedo and Simas, 2000** \\
\hline G. bucchichi males & 115.5 & 0.35 & 3.67 & Sasal et al., 1996 \\
\hline G. bucchichi females & 101.3 & 0.40 & 3.61 & Sasal et al., 1996 \\
\hline G. niger & 166.6 & 0.34 & 3.97 & Silva and Gordo, 1997 \\
\hline G. niger males & 185.2 & 0.30 & 4.01 & Fabi and Gianetti, 1985 \\
\hline G. niger females & 168.6 & 0.19 & 3.73 & Fabi and Gianetti, 1985 \\
\hline G. niger males & 97.7 & 0.40 & 3.58 & Nash, 1984 \\
\hline G. niger females & 91.2 & 0.48 & 3.60 & Nash, 1984 \\
\hline
\end{tabular}

TABLE 5. - Values of the total mortality rate $(\mathrm{Z})$ and the natural mortality $(\mathrm{M})$ and longevity for females and males of $G$. vittatus from the Kvarner area.

\begin{tabular}{|c|c|c|c|c|}
\hline \multirow[t]{2}{*}{ Method } & \multicolumn{2}{|c|}{ Females } & \multicolumn{2}{|c|}{ Males } \\
\hline & Mortality (/years) & Longevity (years) & Mortality (/years) & Longevity (years) \\
\hline The $\mathrm{Z}$ estimation from age composition data & 0.94 & 4.93 & 0.99 & 4.68 \\
\hline The Hoenig's Z estimation & 1.08 & 4.27 & 1.43 & 3.22 \\
\hline The Rikhter and Efanov's M equation & 1.36 & 3.39 & 1.36 & 3.39 \\
\hline The Pauly's M equation & 1.17 & 3.94 & 1.29 & 3.57 \\
\hline The Djabali et al. M equation & 1.03 & 4.47 & 1.11 & 4.16 \\
\hline
\end{tabular}


mated longevities they generated were not reasonable (Table 5). The value of $\mathrm{Z}$ obtained using Hoenig's model 1 was greater and more variable between sexes than the estimate of $\mathrm{Z}$ from the age composition data and the values of $M$ estimated following the Djabali et al. (1994) equation (Table 5).

\section{DISCUSSION}

Year-round samples for research on growth include specimens of the same year class that considerably differ in age (up to 11 months). The variability associated with year-round sampling could be reduced by using mean monthly data for estimating the growth parameters (Labropoulou et al., 1998), or by back calculating the length at capture to the length corresponding to the last annual ring for each fish before estimating the growth parameters (Kovačić, 2001). The method of direct monthly data should provide better results than back calculation, because original data from samples are more accurate (closer to true population values) than calculated estimations. However, direct monthly data cannot be used when the sample of relatively long-lived species is not large enough, because most monthly samples lack some size classes or are too small, especially at the older year classes.

The maximum size of the specimens recorded in this study was smaller than that indicated in other studies, namely $57 \mathrm{~mm}$ for females and $58 \mathrm{~mm}$ for males (Heymer and Zander, 1978; Miller, 1986). The age structure, lifespan, mortality and growth of $G$. vittatus were unknown before the present study. However, present data can be compared with data on closely related Mediterranean species with similar life styles. The dominant age classes were the youngest age groups for both sexes. Therefore, collecting using SCUBA diving and handnets was less selective to age-frequency distributions for G. vittatus than to age-frequency distributions of Gobius bucchichi (Sasal et al., 1996) and Gobius roulei (Kovačić, 2001), where modal values were present in older classes. However, sampling bias due to the collection method could not be excluded in this research, and this could influence the size frequency distribution, sex ratio, and even size differences between sexes.

The growth rate of G. vittatus was an exception with respect to long-lived and slow growing species of the genus Gobius. The growth coefficient of this species was closer to that of smaller European gobiid species with short lifespans ( $K=0.91-2.23$ ) (Kovačić, 2001), than to the Gobius species $(\mathrm{K}=0.19-0.91)$ (Table 4). However, the growth coefficient is again highly variable among different studies, such as in $G$. niger $(\mathrm{K}=0.19-0.91)$ and $G$. paganellus $(\mathrm{K}=0.27-0.89)$ (Table 4$)$. The asymptotic length $\left(\mathrm{L}_{\infty}\right)$ estimated in this study was within the observed total length of females and males. The observed length was found to be higher than the maximum theoretical length in several families (Blenniidae, Gobiidae, Labridae, Scorpaenidae, Sparidae) (Nash, 1982, 1984; Sayer et al., 1995; Massutti et al., 2000; Azevedo and Homem, 2002; Gonçalves et al., 2003). Two explanations have been proposed for these results, and both are applicable to the sample of G. vittatus: size selective sampling of the 0 year class by selecting larger individuals in this class; and very fast growth in the first year of life, slowing down considerably afterwards (Nash, 1984; Gonçalves et al., 2003). No published data exist on the significance of growth differences between sexes of the Gobius species. However, contrary to the present results, in all previously published research males reached a longer length and grew slower than females (Table 4). The growth performance index $\left(\Phi^{\prime}\right)$ yielded little information because it showed high variability within the same species in different research projects, overlap of values among different Gobius species, and considerable similarity in values between sexes of the same species, despite differences in growth parameters between males and females (Table 4).

Among Gobius, the longevity of G. vittatus was similar to Gobius niger, namely 2-5 years (Vaas et al., 1975; Fabi and Giannetti, 1985; Nash, 1984; Vesey and Langford, 1985; Joyeux et al., 1991; Arruda et al., 1993; Silva and Gordo, 1997). Other species of this genus, according to published data, live longer: $G$. bucchichi, 5 years (Sasal et al., 1996); Gobius cobitis, 10 years (Gibson, 1970); Gobius paganellus, 7-10 years (Miller, 1961; Dunne, 1978) and estimated longevity (95\% of $\left.\mathrm{L}_{\infty}\right)$ 3.9 years (Azevedo and Simas, 2000); G. roulei, 7 years (Kovačić, 2001). Among Gobius species with more than one research project on longevity $(G$. niger and G. paganellus), the data on longevity were highly variable among different studies. In contrast to the relatively high longevity of the Gobius species, the short-lived gobiid species (lifespan 1-2 years) of the Mediterranean and the north-eastern 
Atlantic belong mostly to the genus Pomatoschistus (Miller, 1961, 1986; Kovačić, 2001). In most of the research cited above females and males reached the same observed longevity or the difference occurred due to a few older specimens of one sex (Miller, 1961; Fabi and Giannetti, 1985). The only published information on differences in lifespan between sexes of the Gobius species, reported a shorter lifespan for females (Sasal et al., 1996, Kovačić, 2001; Joyeux et al., 1991), and explained it by the reproductive effort of older females. Females of $G$. vittatus lived longer than males, bearing in mind the significantly different average age and the observed longevity in the present research. Compared to other Gobius species with published life histories, G. vittatus exhibits a smaller size, relatively shorter lifespan and a high growth rate.

Most sea fishes can be collected with conventional fishing gears, at least as bycatch. Small gobiids, which inhabit rocky grounds, are one of the rare fish groups whose total mortality rate is unquestionably equivalent to the natural mortality rate, since they are completely out of reach of conventional fishing gears. There is no published estimation of natural and total mortality for gobiids of the Mediterranean and the north-eastern Atlantic. Compared to G. vittatus, the Pacific Istiogobius decoratus has a shorter lifespan $(<1$ year) and higher mortality rate $\left(5.92-7.92\right.$ year $\left.^{-1}\right)$, probably because it lives on sandy bottoms, which are more exposed to predation (Kritzer, 2002). Conversely, G. vittatus, as well as most Gobius species, lives on rocky bottoms with numerous protective shelters where predationinduced mortality is probably lower.

\section{ACKNOWLEDGEMENTS}

I am grateful to M. La Mesa for criticism and comments on this paper. Diving assistance was provided by M. Arko-Pijevac.

\section{REFERENCES}

Alagaraja, K. - 1984. Simple methods for estimation of parameters for assessing exploited fish stocks. Indian J. Fish., 31: 177-208.

Arruda, L.M., J.N. Azevedo and A.I. Neto. - 1993. Abundance, age structure and growth, and reproduction of gobies (Pisces; Gobiidae) in the Ria de Aveiro Lagoon (Portugal). Est. Coast. Shelf Sci., 37: 509-523.

Azevedo, J.M.N. and A.M.V. Simas. - 2000. Age and growth, reproduction and diet of a sublittoral population of the rock goby Gobius paganellus (Teleostei, Gobiidae). Hydrobiologia,
440: $129-135$.

Azevedo, J.M.N. and N. Homem. - 2002. Age and growth, reproduction and diet of the red blenny Parablennius rubber (Blenniidae). Cybium, 26: 129-133.

Beamish, R.J. and D.A. Fournier. - 1981. A method for comparing the precision of a set of age determination. Can. J. Fish. Aquat. Sci., 38: 982-983.

Bernard, D.A. - 1981. Multivariate analysis as a means of comparing growth in fish. Can. J. Fish. Aquat. Sci., 38: 233-236.

De Buen, F. - 1923. Gobius de la Peninsula Iberica y Baleares. Groupos Lesueurii, Colonianus, Affinis y Minutus. Mem. Inst. Esp. Oceanogr., 3: 121-266.

Djabali, F., A. Mehailia, M. Koudil and B. Brahmi. - 1994. A reassessment of equations for predicting natural mortality in Mediterranean teleosts. NAGA,17: 33-34.

Dunne, J. - 1978. Littoral and benthic investigations on the west coast of Ireland - IX (Section A: Faunistic and ecological studies). The biology of the rock-goby, Gobius paganellus L., at Carna. Proc. Royal Irish Acad., 78 B (12): 179-191.

Fabi, G. and G. Gianetti. - 1985: Growth parameters of the black goby (Gobius niger L.) in the Adriatic Sea, based on otoliths reading. Rapp. Comm. Int. Mer Médit., 29: 87-90.

Fage, L. - 1918. Shore-fishes. Rep. Dan. oceanogr. Exped. Med., 2 (A.3): 1-154.

Gayanilo, F.C., P. Sparre and D. Pauly. - 2002. FiSAT II User's Guide. FAO, Rome.

Gibson, R.N. - 1970. Observations on the biology of the giant goby Gobius cobitis Pallas. J. Fish Biol., 2: 281-288.

Gonçalves, J.M.S., L. Bentes, R. Coelho, C. Correia, P.G. Lino, C.C. Monteiro, J. Ribeiro and K. Erzini. - 2003. Age and growth, maturity, mortality and yield-per-recruit for two banded bream (Diplodus vulgaris Geoffr.) from south coast of Portugal. Fish. Res., 62: 349-359.

Heymer, A. and C.D. Zander. - 1978. Morfology and ecology of Gobius vittatus Vinciguerra, 1883, and its possible mimicry relationship to Blennius rouxi Cocco, 1833 in the Mediterranean. Z. Zool. Syst. Evol., 16: 132-143.

Jardas, I. - 1985. Pregled riba (sensu lato) Jadranskog mora (Cyclostomata, Selachii, Osteichthyes) s obzirom na taksomoniju i utvr?eni broj. Biosist., 11 (1): 45-74.

Joyeaux, J.C., J.L. Bouchereau and J.A. Tomasini. - 1991: Croissance et structure démographique de la population de Gobius niger Linné, 1758 (poisson, téléostéen) dans une lagune nord-méditerranéenne. Cah. Biol. Mar., 32: 415-437.

Kolombatović, J. - 1886. Imenik kralješnjaka Dalmacije II dio: Dvoživci, gmazovi i ribe. Godišnje izvješće C. K. Velike realke u Splitu za školsku godinu, 1885/86: 2-32.

Kolombatović, J. - 1891. Glamoči (Gobii) Spljetskog Pomorskog Okružja. Godišnje izvješće C. K. Velike realke u Splitu za školsku godinu, 1890-91: 1-29.

Kovačić, M. - 2001. The biology of Roule's goby in the Kvarner area, northern Adriatic Sea. J. Fish Biol., 59 (4): 795-809.

Kovačić, M. - 2004. Biology and ecology of Gobius vittatus (Gobiidae, Pisces) in the Adriatic Sea (in Croatian). Ph D thesis, Univ. Zagreb, Zagreb.

Kritzer, J.P. - 2002. Stock structure. Mortality and growth of the decorated goby, Istiogobius decoratus (Gobiidae), at Lizard island, Great Barrier Reef. Environ. Biol. Fish., 63: 211-216.

Labropoulou, M., G. Tserpes and N. Tsimenides. - 1998. Age, growth and feeding habits of the brown comber Serranus hepatus (Linnaeus, 1758) on the Cretan shelf. Est. Coast. Shelf Sci., 46: 723-732.

Massutti, E., B. Morales-Nin and J. Moranta. - 2000. Age and growth of blue-mouth. Helicolenus dactylopterus (Osteichthyes: Scorpaenidae), in the western Mediterranean. Fish. Res., 46: 165-176.

Miller, P.J. - 1961. Age, growth, and reproduction of the rock goby Gobius paganellus L., in the Isle of Man. J. Mar. Biol. Ass. U.K., 41: 737-769.

Miller, P.J. - 1986. Gobiidae. In: P.J.P. Whitehead, M.-L. Bauchot, J.-C. Hureau, J. Nielsen, E. Tortonese (eds.), Fishes of the North-eastern Atlantic and the Mediterranean Vol. 3., pp. 1019-1085. UNESCO, Paris.

Munro, J.L. and D. Pauly. - 1983. A simple method for comparing the growth of fishes and invertebrates. Fishbyte, 1: 5-6.

Nash, R.D.M. - 1982. The biology of Fries' goby, Lesueurigobius friesii (Malm), in the Firth of Clyde, Scotland, and a compari- 
son with other stocks. J. Fish Biol., 21: 69-85.

Nash, R.D.M. - 1984. Aspects of the biology of the black goby, Gobius niger L., in Oslofjorden, Norway. Sarsia, 69: 55-61.

Sasal, P., E. Felix and S. Morand. - 1996. Population structure of Gobius bucchichi in a Mediterranean marine reserve and in unprotected area. J. Fish Biol., 49: 352-356.

Sayer, M.D.J., R.N. Gibson and R.J.A. Atkinson. - 1995. Growth, diet and condition of goldsinny on the west coast of Scotland. J. Fish Biol., 46: 317-340.

Silva, M.N. and L.S. Gordo. - 1997. Age, growth and reproduction of the black goby, Gobius niger, from Óbidos Lagoon, Portugal. Cah. Biol. Mar., 38: 175-180.

Sparre, P. and S.C. Venema. - 1992. Introduction to tropical fish stock assessment, part I- Manual. FAO Fish. Tech. Pap., 306/1: 1-376.
Tortonese, E. - 1975. Osteichthyes (Pesci ossei), Parte seconda. Fauna d'Italia, Vol. 11. Calderini, Bologna.

Vaas, K.F., A.G. Vlasblom and P. Koeijer. - 1975. Studies on the black goby (Gobius niger, Gobiidae, Pisces) in the Veerse Meer, SW Netherlands. Neth. J. Sea Res., 9: 56-68.

Vesey, G. and T.E. Langford. - 1985. The biology of the black goby, Gobius niger L. in an English south-coast bay. J. Fish Biol., 27: 417-429.

Vinciguerra, D. - 1883: Resultati ittiologici della crociere del «Violante». Annali Mus. civ. Stor. nat., Genova, 18: 465-590.

Received December 5, 2005. Accepted April 4, 2006.

Scient. ed.: A. Garcia-Rubies

Published online November 13, 2006 
